\title{
Paleogene Glyptodontidae Propalaehoplophorinae (Mammalia, Xenarthra) in extra-Patagonian areas
}

\author{
Alfredo E. Zurita ${ }^{1}$, Laureano R. González-Ruiz² ${ }^{2}$ Angel R. Miño-Boilini' ${ }^{1}$, Rafael Herbst ${ }^{3}$, \\ Gustavo J. Scillato-Yané ${ }^{4}$ Pedro Cuaranta ${ }^{1}$
}

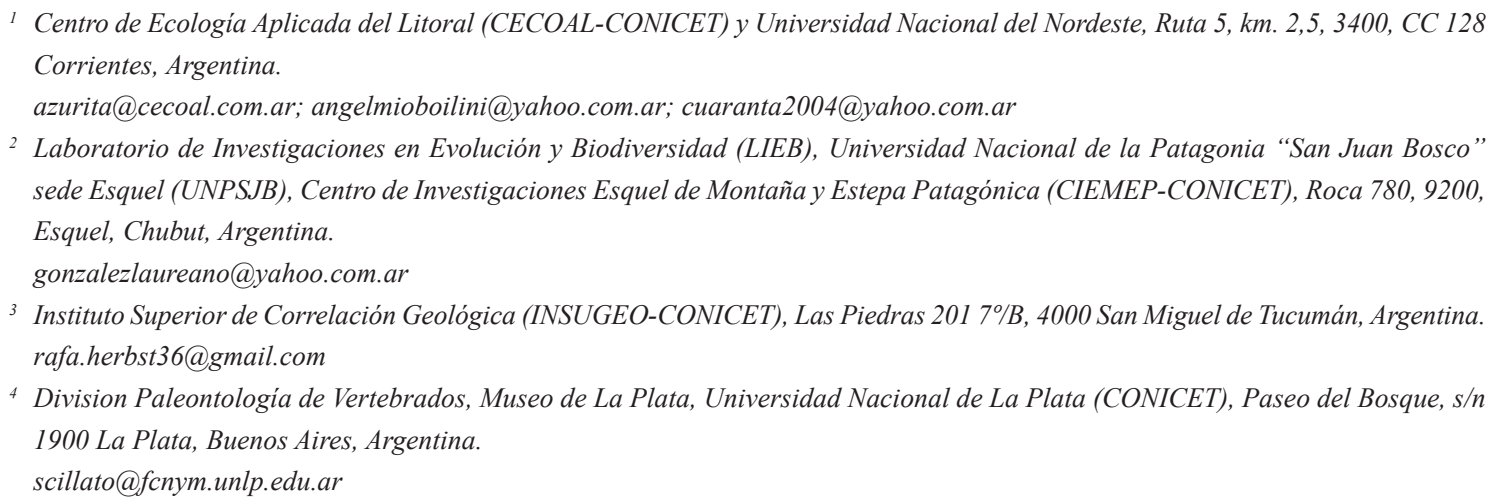

\begin{abstract}
Paleogene records of Cingulata Glyptodontidae are scarce. The only well described comes from the Paleogene of Argentine Patagonia. Two subfamilies have been reported for that period: Glyptatelinae and Propalaehoplophorinae. Until this contribution, the latter taxon was geographically restricted to the locality of El Pajarito (Late Oligocene, Deseadan SALMA), Chubut province, Argentina. Here we present and describe the northernmost record of a Paleogene Propalaehoplophorinae. The material is represented by three associated osteoderms of the dorsal carapace from the Fray Bentos Formation (Late Oligocene, Deseadan SALMA) in the locality of Cueva del Tigre, Chajarí, Entre Ríos province, Argentina. Morphologically, these remains are almost identical to those reported from the late Oligocene of the Patagonian region, showing that during the Paleogene the Propalaehoplophorinae had a larger latitudinal distribution than previously known.
\end{abstract}

Keywords: Glyptodonts, Osteoderms, Mesopotamian Region, Fray Bentos Formation, Oligocene.

RESUMEN. Registros paleógenos de Glyptodontidae Propalaehoplophorinae (Xenarthra, Cingulata) en áreas extrapatagónicas. Los registros paleógenos de Cingulata Glyptodontidae son muy escasos y los mejores conocidos provienen de la actual región patagónica de Argentina. Dos subfamilias han sido descritas: Glyptatelinae y Propalaehoplophorinae. Los registros paleógenos de Propalaehoplophorinae provienen de la localidad El Pajarito (Oligoceno Tardío, SALMA Deseadense), provincia de Chubut, Argentina. Aquí damos a conocer el registro más septentrional de un Propalaehoplophorinae, proveniente de la Formación Fray Bentos (Oligoceno Tardío, SALMA Deseadense) de la localidad Cueva del Tigre, Chajarí, provincia de Entre Ríos, Argentina. Desde una perspectiva morfológica, estos restos son casi idénticos con aquellos reportados para El Pajarito. Esto demuestra que durante el Paleógeno la distribución latitudinal de los Propalaehoplophorinae fue mucho mayor a la previamente conocida. 


\section{Introduction}

The Glyptodontidae (Mammalia, Cingulata) comprise an American endemic clade without extant representatives. During a large period of the Cenozoic, these armored herbivores constituted one of the most conspicuous lineages, reaching enormous sizes during some intervals, especially in the Oligocene and Pleistocene (Scillato-Yané, 1977, 1986; ScillatoYané and Carlini, 1998; Vizcaíno et al., 2011). The oldest records assignable to Glyptodontidae come from the Late Eocene (Mustersian South American Land Mammal Age or SALMA) in the Patagonian region of Argentina and were assigned to the subfamily Glyptatelinae (late Eocene-late Pleistocene). These remains, represented by isolated osteoderms of the dorsal carapace, were described by Ameghino (1902) as Glyptatelus fractus Ameghino (Simpson, 1948; Scillato-Yané, 1977; McKenna et al., 2006). In the Glyptatelinae, the osteoderms of the dorsal carapace are characterized by a central figure displaced posteriorly and surrounded by a row of peripheral figures that are absent on the posterior margin and, in some cases, on the lateral margins as well (Hoffstetter, 1958; Scillato-Yané, 1977).

During the late Oligocene (Deseadan SALMA) a diversification among the Glyptodontidae is observed, and large-sized species such as Clypeotherium magnum Scillato-Yané, 1977 were present among the Glyptatelinae (Scillato-Yané, 1977). The presence of the subfamily Propalaehoplophorinae (Late Oligocene-Middle Miocene) adds to these older records (see Scillato-Yané, 1977; González-Ruiz et al., 2011). From a morphological point of view, the osteoderms of the Propalaehoplophorinae are characterized by a "rosette" ornamentation pattern, i.e., a central figure surrounded by a row of smaller peripheral figures, including some accessory ones (Ameghino, 1889; Scott, 1903-1904).

Most of the few Paleogene records of both subfamilies come from the Argentine Patagonian region. Outside this area, the record is still scarce, and the majority of the materials have not been figured or described. Scillato-Yané (1986, 1988) mentioned the presence of Glyptatelinae nov. sp. and Glyptodontidae incertae sedis for the Late Oligocene (Deseadan SALMA) from Quebrada Fiera, Mendoza province (Argentina). Outside Argentina, Glyptatelinae cf. Glyptatelus sp. was mentioned in the locality of Salla-Luribay (Bolivia) in Late Oligocene sediments
(Deseadan SALMA) (Hoffstetter, 1968; Marshall and Sempere, 1991). Finally, Glyptodontidae incertae sedis was recorded from Fray Bentos Formation (Late Oligocene, Deseadan SALMA), outcropping in Uruguay (Ubilla, 2004; Bostelmann et al., 2010, 2011). In this context, the finding of Paleogene Glyptodontidae becomes important, especially outside Patagonia, because it represents a larger latitudinal distribution for this group during the Oligocene than previously supposed, supporting the presence of other Oligocene cingulates in Fray Bentos Formation (Perea et al., 2014).

Here we describe new remains of Glyptodontidae assignable to Propalaehoplophorinae from the locality of Cueva del Tigre, Entre Ríos province (Argentina) (Fig. 1) from the Fray Bentos Formation (Fig. 2). This is the first extra-Patagonian Paleogene record of these glyptodonts with an adequate description.

\section{Geology}

The Fray Bentos Formation was formally defined by Harrington (1956) in Uruguay, where this unit comprises more than $90 \mathrm{~m}$ in the Santa Lucía basin, but in outcrops only up to $15-18 \mathrm{~m}$, especially along the Uruguay river, from Colonia up north to the Brazilian border (Ubilla, 2004). These are the "Santalucience" and "Palmirense" units, respectively, described by Kraglievich (1932). This unit is mainly composed of fine and medium sandstones, silts, sometimes calcareous, and conglomerates; the dominant colors are reddish-gray and reddish-brown. According to most authors, they are continental, mainly fluvial and only in part eolian (Goso and Bossi, 1966; Ubilla, 2004). Climatically, they were deposited under warm and dry conditions (Ferrando and Dasa, 1974). This unit has also been recognized in Argentina, more precisely in Corrientes and Entre Ríos provinces (Herbst, 1980; Herbst and Santa Cruz, 1999), based on the very close similarity of its lithology and stratigraphic position: directly over the Serra Geral basalts and the Plio-Pleistocene sands and conglomerates of the Salto (or Ituzaingó) Formation (Fig. 2). In Argentina, the unit is composed of "very fine sandstones to silts, with clayish to calcareous-clayish cements" (Herbst, 1980: 309). In the provinces of Corrientes and Entre Ríos, Herbst (1980) recognized two sections: a lower one known as "calcareous sediments of Curuzú Cuatiá" and an upper one composed of reddish lime-sandstones. 


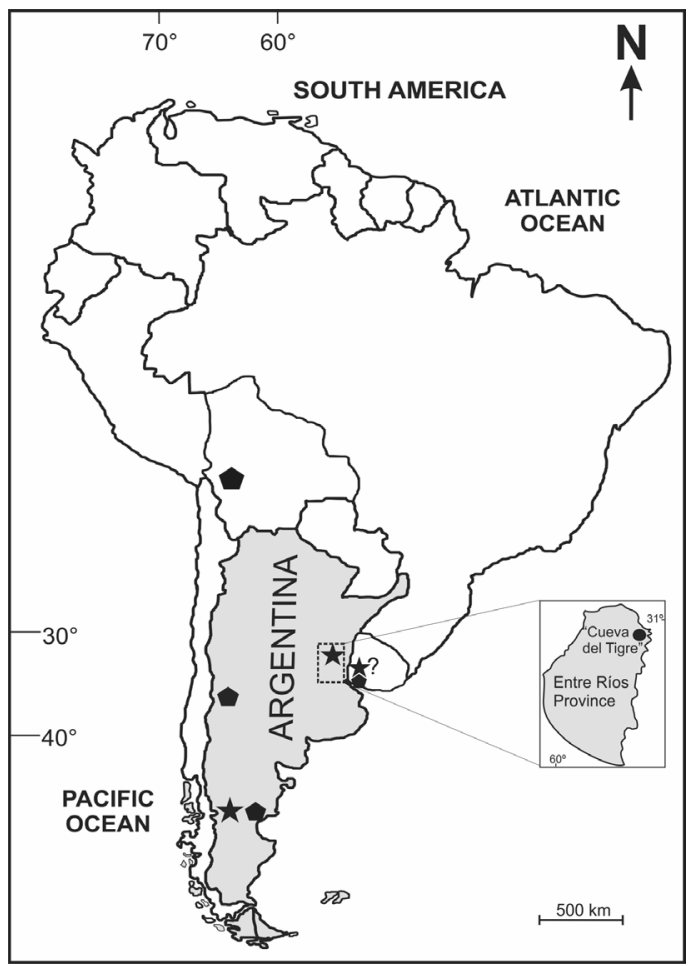

FIG. 1. Map showing fossiliferous localities with Paleogene records of Glyptodontidae. $\downarrow$ Propalaehoplophorinae $\square$ Glyptatelinae.

The materials herein described come from the latter, corresponding to this upper section (Fig. 2).

Traditionally, the Fray Bentos Formation has been assigned to a Deseadan SALMA sensu lato (Álvarez, 1978; Ubilla et al., 1994; Bond et al., 1998), with a time span of 29-24,5 Ma (Bond et al., 1998 and references therein). More recently, the age of the unit has been restricted to the Late Oligocene (Ubilla, 2004; Perea et al., 2014).

\section{Materials and methods}

The materials studied are housed in the paleontological collection of the Universidad Nacional del Nordeste, Facultad de Ciencias Exactas y Naturales y Agrimensura, Corrientes, Argentina (CTESPZ). The materials for comparison correspond to specimens of Glyptatelinae, Propalaehoplophorinae, "Hoplophorinae" Palaehoplophorini, Hoplophorini, and Neosclerocalyptini; Glyptodontinae and Glyptodontidae incertae sedis hosted in the following institutions: American Museum of Natural History, New York, USA (AMNH); División Paleontología de Vertebrados, Facultad de Ciencias Naturales y Museo-Universidad Nacional de La Plata, La Plata, Argentina (MLP); Sección Paleontología de Vertebrados, Museo Argentino de Ciencias Naturales "Bernardino Rivadavia", Buenos Aires, Argentina (MACN); Museo Paleontológico "Egidio Feruglio", Trelew, Argentina (MPEF); Museo Municipal de Ciencias Naturales de Mar del Plata, "Lorenzo Scaglia", Buenos Aires, Argentina (MMP); Museo Nacional de Historia Natural, Santiago, Chile (SGO); Yale Peabody Museum, New Haven, USA (YPM). These include Glyptatelus tatusinus Ameghino, 1897 (MACN A 12361 ex 52-356, type), Glyptatelus malaspinensis Ameghino, 1902 (MACN A 12362 ex 52-357, type), Glyptatelus fractus Ameghino, 1902 (MACN A 12565 ex 52-569, type), Clypeotherium magnum (MLP 61-IV-11-76, type), Propalaehoplophorus australis Ameghino, 1887 (MLP 16-15), P. minus Ameghino, 1891 (AMNH 9197), Cochlops muricatus Ameghino, 1889 (MACN A 2121, YPM-VPPU 16000), Eucinepeltus petesatus Ameghino, 1891 (MPEF Pv 1383), Palaehoplophorus meridionalis Ameghino, 1904 (MACN A-11137, 


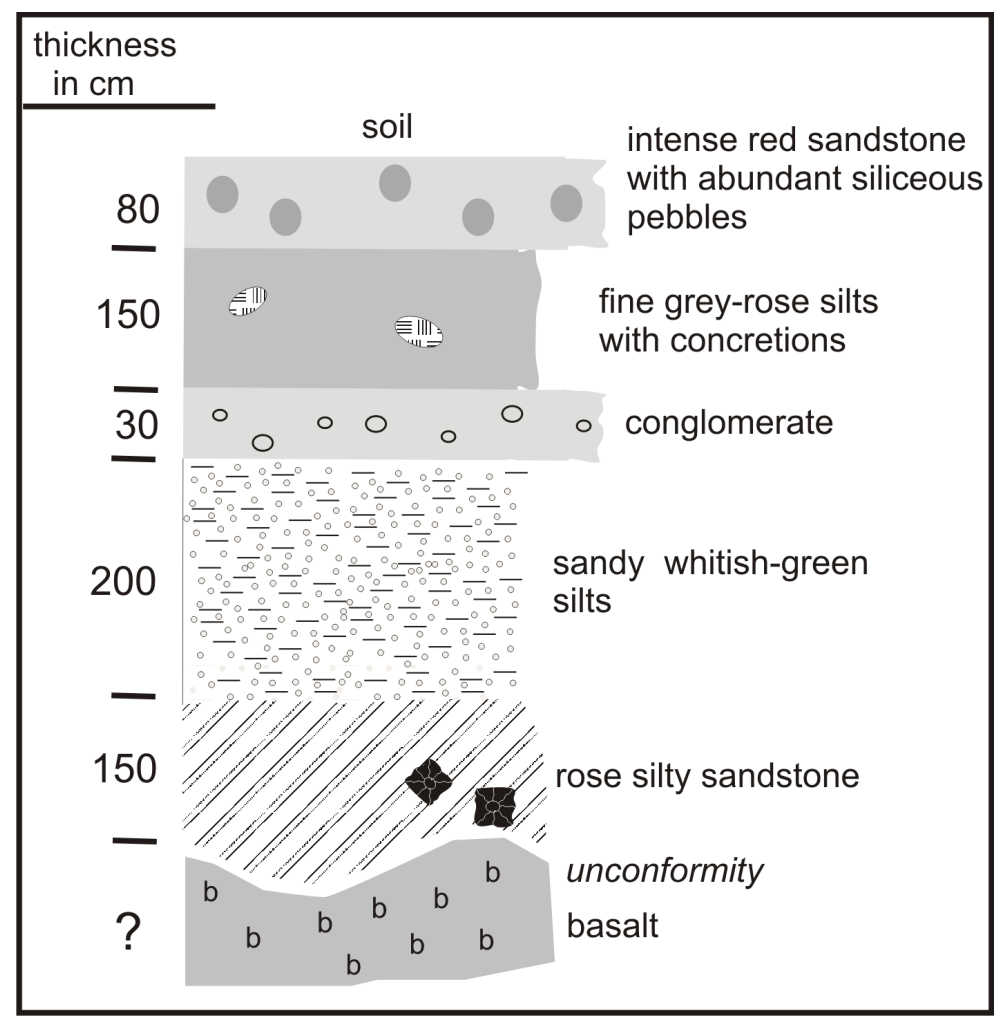

FIG. 2. Stratigraphic profile showing the location of the osteoderms.

syntype), Parapropalaehoplophorus septentrionalis Croft et al., 2007 (SGO PV 4165, type; provisionally housed in Case Western Reserve University School of Medicine, Cleveland, USA), Neosclerocalyptus ornatus Owen 1845 (MLP 16-28) and Glyptodon munizi Ameghino, 1881 (MMP 3985). It was not possible to find the osteoderms referred by ScillatoYané (1977) to a Propalaehoplophorinae gen et sp. indet. (MLP 61-IV-11-208 to 238, MLP 61-IV-11-255 to 266) in the MLP, so comparisons were made with illustrations and descriptions made by Scillato-Yané (1977, plate II, figs. 1-10).

\section{Systematic Paleontology}

Xenarthra Cope, 1889

Cingulata Illiger, 1811

Glyptodontidae Gray, 1869

Propalaehoplophorinae Ameghino, 1887

Propalaehoplophorinae indet.

Fig. 3
Material: CTES-PZ 3512: three associated osteoderms of the dorsal carapace (Fig. 3).

Locality and horizon: Cueva del Tigre, Chajarí, Entre

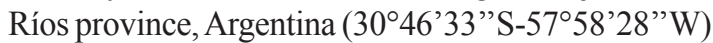
(Fig. 1); Fray Bentos Formation (Deseadan SALMA; late Oligocene) (Fig. 2).

Description and comparisons: The three osteoderms show a finely dotted exposed surface and an evident "rosette" ornamentation pattern (Figs. 3 and 4). This pattern consists of a polygonal central figure delimited by a central groove, from which radial grooves that define peripheral figures (anterior, lateral and posterior) emerge and surround the central one. An evident foramen is present in most of the intersections between the radial grooves and the groove that defines the central figure (Ameghino, 1889). The grooves delimiting the peripheral figures are shallow and parabolic in sagittal section ("V"shaped; see Carlini et al., 2008). The osteoderms present $11(\mathrm{~A}), 10(\mathrm{~B})$ and $11(\mathrm{C})$ peripheral figures surrounding the central figure, while two osteoderms have 2 (A), 1 (B) and 4 (C) latero-anterior accessory 


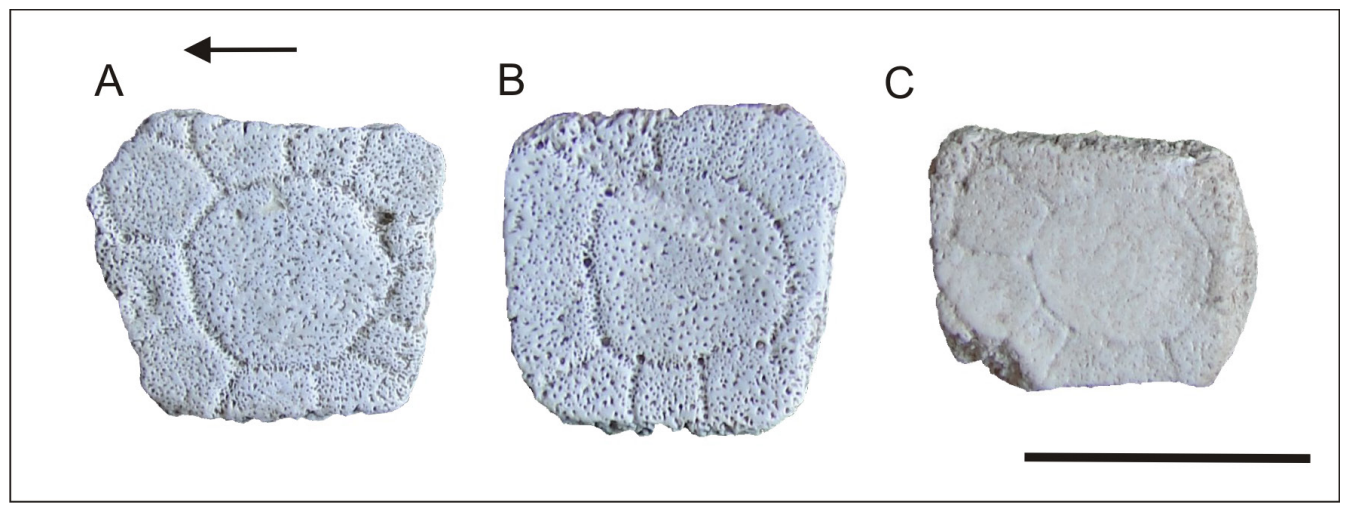

FIG. 3. CTES-PZ 3512. Three associated osteoderms from the lateral region of the dorsal carapace (A,B,C). Scale bar: $30 \mathrm{~mm}$.

peripheral figures (Figs. 3 and 4). The presence of these small accesory figures allows assigning these osteoderms to the lateral region of the dorsal carapace, because it is the region in the carapace of the Propalaehoplophorinae where they are usually developed.(Scott, 1903-1904; González, 2010). One of the osteoderms (Fig. 3C) probably corresponds to a more lateral region of the carapace, since it has a great development of the anterior peripheral figures, while the posterior ones are much less visible, as observed in the Neogene species of Propalaehoplophorinae (e.g., Propalaehoplophorus minus).

The contact area and articulation between adjacent osteoderms is relatively flat, although rather rough. The ventral surface of each osteoderm is slightly concave in its central area, where 3-6 larger foramina can be seen. The osteoderms measure: (A) $35.24 \mathrm{~mm}$ (antero-posterior diameter) x $26.56 \mathrm{~mm}$ (dorso-ventral diameter) $\times 9.71 \mathrm{~mm}$ (transverse diameter); (B) $32.65 \mathrm{~mm}$ x $32.42 \mathrm{~mm}$ x $9.85 \mathrm{~mm}$; (C) $37.44 \mathrm{~mm}$ x $31.42 \mathrm{~mm}$ x $9.27 \mathrm{~mm}$. (Fig. 2).

The morphology of the exposed surface of the osteoderms described here is clearly different from that of Paleogene Glyptatelinae (Glyptatelus fractus, Glyptatelus tatusinus and Clypeotherium magnum), in which the central figure reaches the posterior edge, the peripheral figures are limited to the anterior and lateral edges (the lateral ones generally reduced or absent), there are no accessories latero-anterior peripheral figures, and the figures are convex and rounded (except in Clypeotherium where they are flat), and the grooves that delimit the figures are deep (Ameghino, 1897; Hoffstetter, 1958; Scillato-Yané, 1977. In addition to this, we observed only two or three large anterior figures in most of the osteoderms, whereas in Glyptodontidae Propalaehoplophorinae there are generally four. In this scenario, it is remarkable that most of the Glyptatelinae characters are absent in Glyptatelus malaspinensis, suggesting that the type material (osteoderms) corresponds in fact to a Propalaehoplophorinae, but further studies are necessary. Compared to Parapropalaehoplophorus (Glyptodontidae incertae sedis) the osteoderms of Propalaehoplophorinae indet. From the Fray Bentos Formation are different because they have conspicuous foramina in the intersection of the grooves that delimit the figures and the presence of the typical "rosette" pattern, both characters absent in Parapropalaehoplophorus.

\section{Discussion}

At the level of the osteoderms of the dorsal carapace, the "rosette" ornamentation pattern (i.e., a central figure surrounded by a complete row of peripheral figures) appears for the first time in Propalaehoplophorinae glyptodonts (Ameghino, 1889; Scott, 1903-1904) during the Late Oligocene (see Scillato-Yané, 1977). This pattern probably originated from a previous one (with a smaller number of lateral peripheral figures and absence of posterior peripheral figures) present in the Glyptatelinae and in a Glyptodontidae incertae sedis (Parapropalaehoplophorus) of the Early and Middle Miocene of northern Chile and Perú (Hoffstetter, 1958; Carlini et al., 1997; Croft et al., 2007; Tejada et al., 2011). Although the Glyptatelinae pattern is apparently observed in Parapropalaehoplophorus, 

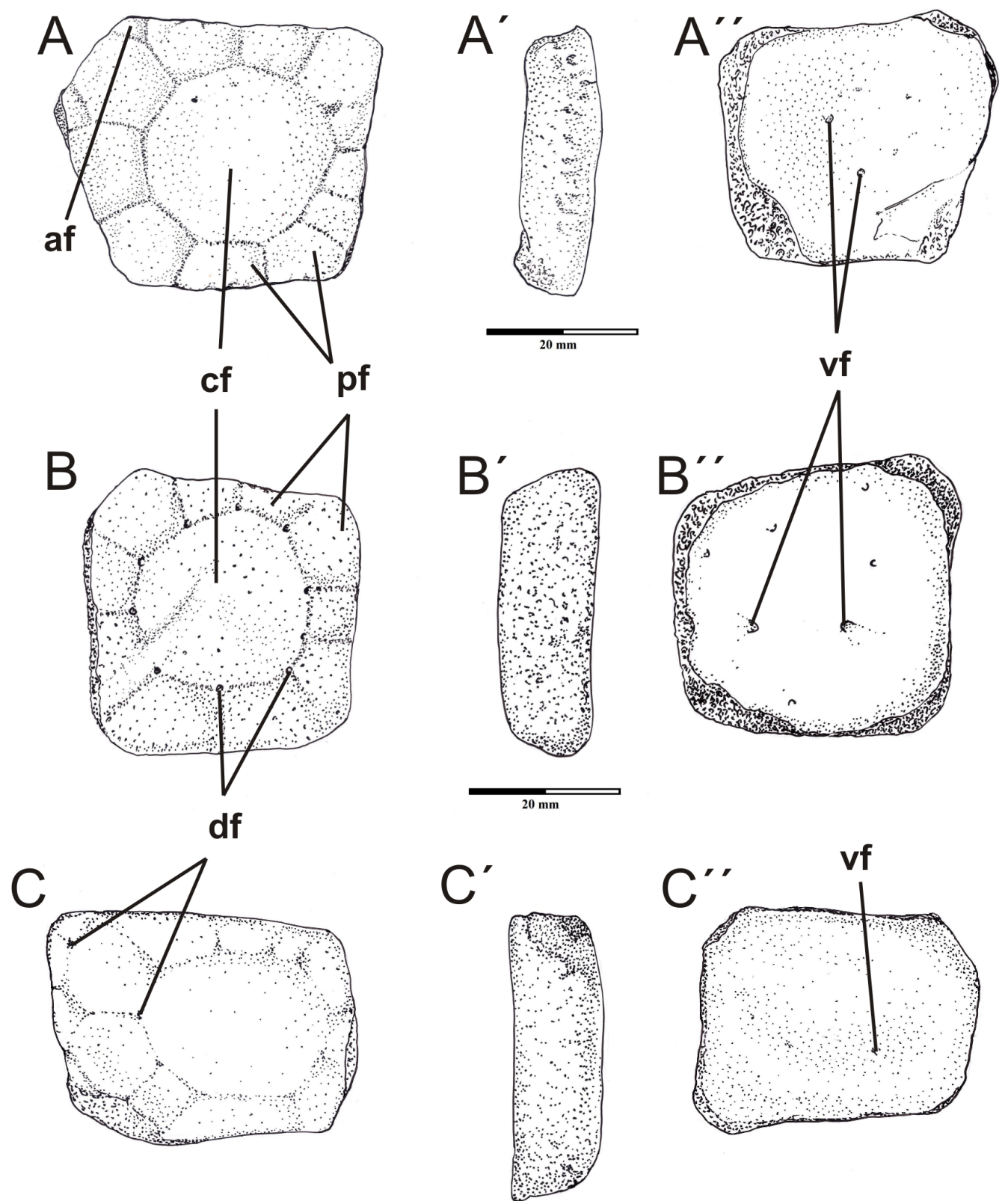

FIG. 4. Anatomical nomenclature used in this contribution. cf: central figure; pf: peripheral figures; af: accessories figures; df: dorsal foramina; vf: ventral foramina. A-C: dorsal views; $\mathbf{A}^{\prime}$-C': lateral views; $\mathbf{A}^{\prime \prime}-\mathbf{C}^{\prime \prime}$ : ventral views. Scale bar: $20 \mathrm{~mm}$.

in some osteoderms from the lateral region of the carapace of the Propalaehoplophorinae, and in fixed osteoderms of Cingulata Dasypodidae, there are differences between all of them, such as the position of the central (=principal) figure in dorsal osteoderms (along the posterior edge, near posterior edge, or roughly central, among others; see Croft et al., 2007).
The "rosette" pattern is present practically unchanged in all genera of Propalaehoplophorinae (see Scott, 1903-1904; Scillato-Yané, 1977, 1986; González, 2010). In the genus Cochlops Ameghino, 1889 , at the level of the pelvic region, osteoderms present a clear "cone-like" elevation, in both central and peripheral figures, showing some analogy 
with that observed in the peripheral osteoderms of Glyptodontinae (Ameghino, 1889; Zurita et al., 2013). In the same region, Propalaehoplophorus shows some convexity in the central figures of the osteoderms although such elevation is not as marked as in Cochlops. However, in any case, the "rosette" pattern is not modified.

The comparison between the Oligocene osteoderms described and figured by Scillato-Yané (1977) and those studied here shows that there are no significant differences in morphology or size. In fact, the osteoderms A and B figured here are almost identical to those figured by Scillato-Yané (1977, plate II) as 1 and 3 , whereas the osteoderm $C$ is very similar to that figured and numbered as 7 .

This "rosette" pattern is also present in several lineages of subsequent glyptodonts, such as some "Hoplophorinae" Palaehoplophorini (González, 2010; González et al., 2011) and Neosclerocalyptini (Zurita, 2007), and in the subfamily Glyptodontinae (Ameghino, 1889; Zurita et al., 2013). However, these groups show very marked differences compared to the Propalaehoplophorinae. In the Palaehoplophorini (Middle Miocene-Late Miocene; Scillato-Yané and Carlini, 1998; González, 2010; Scillato-Yané et al., 2013) it is possible to observe several different morphologies. In Palaehoplophorus meridionalis Ameghino, some osteoderms have a rough exposed surface with grooves delimiting the central figure and the peripheral ones, which are wider and deeper (González, 2010). Other species have two or three rows of small peripheral figures and a depressed central figure (e.g., Palaehoplophorus antiquus Ameghino, 1883) (Scillato-Yané et al., 2013), whereas others may show a series of clearly circular small peripheral figures (e.g., Aspidocalyptus castroi Cabrera, 1939).

The Neosclerocalyptini (e.g., Neosclerocalyptus) also show a "rosette" ornamentation pattern, which, in some sectors of the carapace, presents a remarkable similarity with the Propalaehoplophorinae (see Zurita, 2007). However, and in contrast to that observed in this subfamily, the lateral osteoderms show an equivalent development of the peripheral figures in the anterior and posterior edges. In fact, in the Propalaehoplophorinae, the more antero-lateral region of the carapace presents a very different morphology from that of Eosclerocalyptus C. Ameghino, 1919 and Neosclerocalyptus Paula Couto, 1957. In Neosclerocalyptini, the osteoderms of this region have a pentagonal or hexagonal outline while in the
Propalaehoplophorinae the osteoderms have a clear rectangular morphology.

Finally, another group is represented by the subfamily Glyptodontinae (middle-late Mioceneearly Holocene) (e.g., Boreostemma Carlini et al., 2008 and Glyptodon Owen, 1839). However, in this clade, there are trends that allow differentiating them from the Propalaehoplophorinae. This group shows a progressive increase in the roughness of the exposed surface, an increase in the denticulation of the area of contact between adjacent osteoderms, an increase in the thickness of the osteoderms, and grooves that delimit the figures in " $U$ " shape, together with the absence of additional small peripheral figures and fewer small peripheral figures (Carlini et al., 2008; Zurita et al., 2013).

\section{Conclusions}

The comparative study shows that the morphology of the exposed surface of the osteoderms studied in this contribution is almost identical to the other Paleogene record assigned to Propalaehoplophorinae coming from the Patagonian region of Argentina. From a paleobiogeographical perspective, as mentioned above, the Paleogene records of Propalaehoplophorinae are scarce. Until this contribution, these were limited with certainty to one record from the Argentine Patagonia (Scillato-Yané, 1977). Although Bostelmann et al. (2010) mentioned the probable presence of Propalaehoplophorinae indet. In Nueva Palmira (Uruguay), he reinterpreted the specimens as belonging to Glyptodontidae incertae sedis (Bostelmann et al., 2011). However, only the Patagonian Propalaehoplophorinae records have been figured (Scillato-Yané, 1977, plate II).

In summary, this is the northernmost record of a Paleogene Propalaehoplophorinae, thus significantly expanding its latitudinal distribution, which now ranges from $43^{\circ} 51^{\prime} \mathrm{S}$ to $30^{\circ} 46^{\prime} \mathrm{S}$. This indicates that during the Paleogene, the Propalaehoplophorinae had a larger latitudinal distribution than previously supposed.

\section{Acknowledgments}

The authors wish to thank D. Croft for the pictures of Parapropalaehoplophorus. Dr. E. Bostelmann read the manuscript and made lots of useful comments. This contribution was partially founded by project grants PI Q 001/13 (SGCyT-UNNE) and PIP 0150 (CONICET). 


\section{References}

Álvarez, B.B. 1978. Noticias sobre una fauna de la Formación Fray Bentos (Oligoceno inferior), provincia de Corrientes, Argentina. FACENA 2: 253-258.

Ameghino, F. 1881. La antigüedad del hombre en el Plata 2: 1-557. París-Buenos Aires.

Ameghino, F. 1883. Sobre una colección de mamíferos fósiles del piso mesopotámico de la formación patagónica recogidos por el Profesor Pedro Scalabrini. Boletín de la Academia Nacional de Ciencias en Córdoba 5: 1-34. Buenos Aires.

Ameghino, F. 1887. Enumeración sistemática de las especies de mamíferos fósiles coleccionados por Carlos Ameghino en los terrenos eocenos de Patagonia austral y depositados en el Museo de La Plata. Boletín del Museo de La Plata 1: 1-26. Buenos Aires.

Ameghino, F. 1889. Contribución al conocimiento de los mamíferos fósiles de la República Argentina. Actas de la Academia Nacional de Ciencias en Córdoba 6: 1-1027.

Ameghino, F. 1891. Mamíferos y aves fósiles argentinas. Especies nuevas, adiciones y correcciones. Revista Argentina de Historia Natural 1 (4): 240-259.

Ameghino, F. 1897. Mammifères crétacés de l'Argentine. Boletín del Instituto Geográfico Argentino 18 (4-6): 406-521.

Ameghino, F. 1902. Notices préliminaires sur les Mammifères nouveaux des terrains crétacés de Patagonie. Boletín de la Academia Nacional de Ciencias en Córdoba 17: 5-70.

Ameghino, F. 1904. Nuevas especies de mamíferos cretáceos y terciarios de la República Argentina. Anales de la Sociedad Científica Argentina 58: 56-291.

Ameghino, C. 1919. Sobre mamíferos fósiles del Piso Araucanense de Catamarca y Tucumán. In Reunión Nacional de la Sociedad Argentina de Ciencias Naturales, No. 1, Actas: 151-152. Láminas III y VII.

Bond, M.; López, G.; Reguero, M.A.; Scillato-Yané, G.J.; Vucetich, M.G. 1998. Los Mamíferos de la Formación Fray Bentos (Edad Mamífero Deseadense, Oligoceno Superior?) de las Provincias de Corrientes y Entre Ríos, Argentina. Paleógeno de América del Sur y de la Península Antártica. Asociación Paleontológica Argentina, Publicación Especial 5: 41-50.

Bostelmann, E.; Rinderknecht, A.; Ciancio, M.R.; Toriño, P.; Perea, D. 2010. Oligocene Glyptodontidae (Mammalia, Cingulata) from the Fray Bentos Fomation of Uruguay. In Congreso Uruguayo de Zoología, No. 1, y Jornadas de Zoología del Uruguay, No. 10, "Prof. Federico Achaval": 74. Montevideo.

Bostelmann, E.; Ciancio, M.R.; Rinderknecht, A.; Perea, D. 2011. The Cingulata (Mammalia, Xenarthra) of the Fray Bentos Formation (Late Oligocene) of Uruguay. Ameghiniana 48 (4): R145-R146.

Cabrera, A. 1939. Sobre vertebrados fósiles del Plioceno de Adolfo Alsina. Revista del Museo de La Plata (Nueva Serie) 2 (6): 3-35. La Plata.

Carlini, A.A.; Vizcaíno, S.F.; Scillato-Yané, G.J. 1997. Armored Xenarthrans: a unique taxonomic and ecologic assemblage. In Vertebrate Paleontology in the Neotropics. The Miocene Fauna of La Venta, Colombia (Richard, R.H.M.; Kay, R.; Cifelli, R.; Flynn, J.J.; editors). Smithsonian Institution Press: 213-226. Washington and London.

Carlini, A.A.; Zurita, A.E.; Scillato-Yané, G.J.; Sánchez, R.; Aguilera, O. 2008. New Glyptodont from the Codore Formation (Pliocene), Falcón State, Venezuela, its relationship with the Asterostemma problem, and the paleobiogeography of the Glyptodontinae. Paläeontologische Zeitschrift 82 (2): 139-152.

Cope, E. 1889. The Edentata of North America. The American Naturalist 23: 657-664.

Croft, D.A.; Flynn, J.J.; Wyss, A.R. 2007. A new basal Glyptodontoid and other Xenarthra of the early Miocene Chucal Fauna, Northern Chile. Journal of Vertebrate Paleontology 27 (4): 781-797.

Ferrando, L.; Dasa, M. 1974. Mineralogía de la fracción arcillosa de la Formación Fray Bentos. In Congreso Brasilero de Geología, No. 28, Actas 2: 3-13. Porto Alegre.

González, L.R. 2010. Los Cingulata (Mammalia, Xenarthra) del Mioceno temprano y medio de Patagonia (edades Santacrucense y "Friasense"). Revisión sistemática y consideraciones bioestratigráficas. Ph.D. Thesis (Unpublished), Universidad Nacional de La Plata: 471 p.

González, L.R.; Zurita, A.E.; Scillato-Yané, G.J.; Zamorano, M.; Tejedor, M.F. 2011. Un nuevo Glyptodontidae (Mammalia, Xenarthra, Cingulata) del Mioceno de Patagonia (Argentina) y comentarios acerca de la sistemática de los gliptodontes del SALMA "Friasense". Revista Mexicana de Ciencias Geológicas 28 (3): 566-579.

Goso, H.; Bossi, J. 1966. Cenozoico. In Geología del Uruguay (Goso, H; editor). Departamento de Publicaciones, Universidad de la República: 469 p. Montevideo.

Gray, J.E. 1869. Catalogue of carnivorous, pachydermatous and edentate Mammalia in the British Museum. British Museum (Natural History): 398 p. London. 
Harrington, H. 1956. Uruguay. In Handbook of South American geology. An explanation of the geologic map of South America (Jenks, W.; editor). Memories of the Geological Society of America 65: 115-128.

Herbst, R. 1980. Consideraciones estratigráficas y litológicas sobre la Formación Fray Bentos (Oligoceno inferior-medio) de Argentina y Uruguay. Revista de la Asociación Geológica Argentina 34 (3): 308-317.

Herbst, R.; Santa Cruz, J.N. 1999. Mapa litoestratigráfico de la provincia de Corrientes. D’Orbignyana 2: 1-69.

Hoffstetter, R. 1958. Xenarthra. In Traité de Paléontologie (Piveteau, P.; editor). Masson et Cie 2 (6): 535-636. Paris.

Hoffstetter, R. 1968. Un gisement de mammifères déséadiens (Oligocène inférieur) en Bolivie. Compte Rendu de l'Académie des Sciences 267:1095-1097.

Illiger, C. 1811. Prodromus Systematics Mammalium et Avium Additis Terminis Zoographicis Utriusque Cassis. Sumptibus C. Salfeld: 301 p. Berlín.

Kraglievich, L. 1932. Nuevos apuntes para la geología y paleontología de la República Oriental del Uruguay. Anales del Museo de Historia Natural de Montevideo 2: 257-321.

Marshall, L.G.; Sempere, T. 1991. The Eocene to Pleistocene vertebrates of Bolivia and their stratigraphic context: a review. In Fósiles y Facies de Bolivia (Suárez-Soruco, R.; editor). Revista Técnica de YPFB 12 (1): 631-652.

McKenna, M.C.; Wyss, A.R.; Flynn, J.J. 2006. Paleogene Psudoglyptodont Xenarthrans form Central Chile and Argentine Patagonia. American Museum Novitates 3536: 1-18.

Owen, R. 1839. Description of a tooth and part of the skeleton of the Glyptodon, a large quadruped of the edentate order, to which belongs the tessellated bony armour figured by Mr. CLIFT in his memoir on the remains of the Megatherium, brought to England by Sir Woodbine PARISH, F.G.S. Proceedings of the Geological Society of London 3: 108-113

Owen, R. 1845. Descriptive and illustrated catalogue of the fossil organic remains of Mammalia and Aves contained in the Museum of the Royal College of Surgeons of London: $391 \mathrm{p}$.

Paula-Couto, C. 1957. Sôbre um gliptodonte do Brasil. Boletim Divisão de Geologia e Mineralogia 165:1-37. Río de Janeiro.

Perea, D.; Toriño, P.; Ciancio, M. 2014. La presencia del xenartro Palaeopeltis inornatus Ameghino, 1894, en la Formación Fray Bentos (Oligoceno tardío), Uruguay. Ameghiniana 51 (3): 254-258.
Scillato-Yané, G.J. 1977. Sur quelques Glyptodontidae nouveaux (Mammalia, Edentata) du Déséadien (Oligocène inférieur) de Patagonie (Argentine). Bulletin du Muséum National D'Histoire Naturelle 64: 249-262.

Scillato-Yané, G.J. 1986. Los Xenarthra fósiles de Argentina (Mammalia, Edentata). In Congreso Argentino de Paleontología y Bioestratigrafía, No. 4, Actas 2: 151-155. Mendoza.

Scillato-Yané, G.J. 1988. Algunos Cingulata (Mammalia, Edentata) del Oligoceno de Quebrada Fiera (Mendoza, Argentina). In Jornadas Argentinas de Paleontología de Vertebrados, No. 5, Resúmenes: p. 26. La Plata, Buenos Aires.

Scillato-Yané, G.J.; Carlini, A.A. 1998. Un gigantesco Gliptodonte en los alrededores de la Ciudad de La Plata. Museo 2 (11): 45-48.

Scillato-Yané, G.J.; Góis, F.; Zurita, A.E.; Carlini, A.E.; González-Ruiz, L.R.; Krmpotic, C.M.; Oliva, C.; Zamorano, M. 2013. Los Cingulata (Mammalia, Xenarthra) del "Conglomerado Osífero" (Mioceno tardío) de la Formación Ituzaingó de Entre Ríos, Argentina. In El Neógeno de la Mesopotamia argentina (Brandoni, D.; Noriega, J.I.; editors). Asociación Paleontológica Argentina, Publicación Especial 14: 118-134.

Scott, W.B. 1903-1904. Mammalia of the Santa Cruz Beds. I Edentata. Reports of the Princeton University Expedition to Patagonia (1896-1899) 5:1-226. Princeton.

Simpson, G.G. 1948. The beginning of the Age of Mammals in South America. Bulletin of the American Museum of Natural History 91: 1-232.

Tejada, J.; Antoine, P-O.; Baby, P.; Pujos, F.; SalasGismondi, R. 2011. Basal or not basal cingulates in the middle Miocene of Peruvian Amazonia. Ameghiniana 48, Suplemento Resúmenes 4: R128-R129.

Ubilla, M.; Perea, D.; Bond, M. 1994. The Deseadan Land-Mammal-Age in Uruguay and the report of Scarrittia robusta n.sp. (Leontiniidae, Notoungulata) in the Fray Bentos Formation (Oligocene-?Lower Miocene). Geobios 27: 95-102.

Ubilla, M. 2004. La Formación Fray Bentos (Oligoceno Tardío) y los Mamíferos más antiguos de Uruguay. In Cuencas Sedimentarias de Uruguay (Veroslavsky, M.; Ubilla, M; Martínez, M.; editores), DIRAC, Facultad de Ciencias: 83-104. Montevideo.

Vizcaíno, S.F.; Cassini, G.H.; Fernicola, J.C.; Bargo, M.S. 2011. Evaluating habitats and feeding habits through ecomorphological features in glyptodonts (Mammalia, Xenarthra). Ameghiniana 48 (3): 305-319. 
Zurita, A.E. 2007. Sistemática y evolución de los Hoplophorini (Xenarthra, Glyptodontidae, Hoplophorinae. Mioceno tardío-Holoceno temprano). Importancia bioestratigráfica, paleobiogeográfica y paleoambiental. Ph.D. Thesis (Unpublished), Universidad Nacional de La Plata: 363 p.
Zurita, A.E.; González-Ruiz, L.; Gómez-Cruz, A.; ArenasMosquera, J.E. 2013. The most complete known Neogene Glyptodontidae (Mammalia, Xenarthra, Cingulata) from northern South America: taxonomic, paleobiogeographic and phylogenetic implications. Journal of Vertebrate Paleontology 33: 696-708.

Manuscript received: November 19, 2014; revised/accepted: September 22, 2015; available online: September 23, 2015. 